\title{
Comparison of clonidine and dexmedetomidine as adjuvants for ropivacaine in supraclavicular brachial plexus block
}

\author{
Ovais Nazir ${ }^{1 *}$, Asif Hussain Bhat ${ }^{1}$, Tarun Sharma ${ }^{1}$, Amit Khatuja ${ }^{2}$, Rajesh Misra ${ }^{3}$ \\ Senior Resident ${ }^{l}$, Department of Anaesthesia, Aruna Asif Ali Government hospital, New Delhi, India \\ Senior Consultant ${ }^{2}$, Chairperson and Head ${ }^{3}$, Department of Anaesthesiology, Artemis Health \\ Institute, Haryana, India.
}

Background: Addition of adjuvants to local anaesthetic in supraclavicular brachial plexus block helps in improving duration of block and analgesia. We compare clonidine and dexmedetomidine as adjuvants to ropivacaine in supraclavicular brachial plexus block.

\begin{abstract}
Method: A total of 75 patients aged from 20 to 60 years belonging to ASA I-II scheduled for upper limb surgery were included and divided into three groups- Group I received $0.5 \%$ ropivacaine plus normal saline, Group II received $0.5 \%$ ropivacaine plus clonidine and Group III received $0.5 \%$ ropivacaine plus dexmedetomidine. The patients were compared for onset as well as duration of sensory and motor blockade, duration of analgesia and haemodynamic side effects.
\end{abstract}

Results: The mean duration of sensory and motor block as well as analgesia was found to be more (statistically highly significant $\mathrm{p}<0.001$ ) in group III (dexmedetomidine group) having a much longer duration of sensory and motor block as well as analgesia compared to group I (plain ropivacaine) and group II (clonidine group).

Conclusion: Therefore, in present study it was found that addition of clonidine and dexmedetomidine to $0.5 \%$ ropivacaine are effective in supraclavicular brachial plexus block. However, dexmedetomidine is a better alternative to clonidine as adjuvant for $0.5 \%$ ropivacaine in to obtain early onset and prolong the duration of sensory and motor block and postoperative analgesia.

Keywords: Dexmedetomidine; clonidine; ropivacaine; supraclavicular brachial plexus block

\section{Introduction}

Brachial plexus blockade is the cornerstone of regional anaesthesia practice of most anaesthesiologists. The supraclavicular approach is one of several techniques used to accomplish anaesthesia of the brachial plexus and is performed at the level of the brachial plexus trunks where almost entire sensory, motor and sympathetic nerve supply of the upper extremity is carried. Consequently, typical features of this block include its rapid onset, predictability and density. ${ }^{1}$

*Correspondence: Ovais Nazir

E mail: ovais.khan83@gmail.com

https://orcid.org/0000-0002-0785-4434

Received: 20/11/2018

Accepted:17/01/2019

DOI: http://doi.org/10.4038/slja.v27i1.8393
Long acting local anaesthetics have advantage of longer duration of block and prolonged postoperative analgesia to help reduce postoperative analgesic requirement. Ropivacaine, one of the newer long acting amide local anaesthetics, is the stereo isomer of bupivacaine and has been shown in to be less toxic than bupivacaine when injected intravenously. ${ }^{2}$ The addition of an adjuvant to ropivacaine can further have the advantage of prolonging the duration of block and postoperative analgesia as well as decrease the dose of ropivacaine required. ${ }^{3}$

In this regard alfa-2 agonists, previously used as antihypertensive agents, have been utilized as adjuvants to local anaesthetics in nerve blocks. Clonidine, an imidazole, with selective partial agonist activity at alpha 2 adrenergic receptors, is being used to prolong the duration of analgesia when used in combination with local anaesthetic agents. ${ }^{4}$ Dexmedetomidine, a highly selective alpha 2 adrenoreceptor agonist (1600 folds more selective for alpha 2 receptors) with sedative, 
sympatholytic and analgesic properties ${ }^{5}$ have been found to be safe and effective in various neuraxial blocks and regional anaesthesia and has been shown to improve the quality of anaesthesia and reduce postoperative analgesia requirement. ${ }^{5,6}$

The present study was undertaken to compare the efficacy and safety of clonidine and dexmedetomidine as adjuvants for ropivacaine in supraclavicular brachial plexus block and to assess the sensory and motor blockade in terms of their onset and duration, duration of pain relief and side effects.

\section{Materials and methods}

After approval by institutional ethical committee and obtaining written informed consent from patients, this prospective randomised study was done from April 2013 to March 2014. A total of 75 patients aged 20 to 65 years belonging to American Society of Anesthesiologists (ASA) physical status I-II, scheduled for upper limb surgeries were allocated into three groups randomly (randomization by computer generated random table method) with 25 patients in each group:

- Group I: Patients who received $29 \mathrm{ml}$ ropivacaine $0.5 \%$ plus $1 \mathrm{ml}$ saline.

- Group II: Patients who received $29 \mathrm{ml}$ ropivacaine $0.5 \%$ and $1 \mathrm{ml}$ clonidine (50mcg).

- Group III: Patients who received $29 \mathrm{ml}$ ropivacaine and $1 \mathrm{ml}$ dexmedetomidine (50 mcg).

Identical syringes were prepared by the anaesthesiologist not involved with the rest of the study. Patients with history of bleeding disorders and those receiving anticoagulants, pregnant females, ASA III or more were excluded from study.

On arrival at operating room monitors to record heart rate, blood pressure and oxygen saturation $\left(\mathrm{S}_{\mathrm{P}} \mathrm{O}_{2}\right)$ were established.

\section{Anaesthetic technique}

The patients were made to lie supine on OT table, with head turned towards the opposite side.

The following landmarks were marked with the marker:
1. Clavicle from sternoclavicular joint to acromioclavicular joint.

2. Midpoint of clavicle.

3. One centimeter superior to the clavicular mid-point.

Neural localization was achieved using a nerve stimulator (Stimuplex, Braun, Germany) connected to a 22-gauge needle (Biometer, Melsungen, Germany). The position of the needle was judged adequate when an output current of $0.3-0.7 \mathrm{~mA}$ elicited a distal motor response. After frequent negative aspirations, local anaesthesia solution (already prepared according to specific groups) was injected slowly into the brachial plexus sheath. All the patients were then assessed for onset of sensory and motor block and intraoperative haemodynamic variables.

Sensory block was assessed by pinprick method and compared with the same stimulation on contralateral arm.

$>$ 0: Sharp pain

> 1: Touch sensation only

$>\quad$ 2: Not even touch sensation

Sensory score of 2 will be taken as the time of onset of sensory block

Motor block was assessed by Bromage scale on the three-point scale:

$>0$ : Normal motor function with full flexion and extension of elbow, wrist and fingers.

$>\quad$ 1: Decreased motor strength with ability to move fingers only

$>\quad$ 2: Complete motor block with inability to move fingers

Motor score of 2 was taken as the onset time of complete motor block.

\section{Data analysis}

Statistical analysis was performed by the SPSS program for Windows, version 17.0. Continuous variables were presented as mean $\pm \mathrm{SD}$, and categorical variables as absolute numbers and percentages. Data was checked for normality before statistical analysis using Shaipro Wilk test. Normally distributed continuous variables were compared using ANOVA. If the $\mathrm{F}$ value was significant Bonferroni or Tamhanne multiple comparison test was used to assess the differences between the individual groups. Categorical variables were analyzed using the chi-square test. For all statistical tests, a p-value less than 0.05 were taken to indicate a statistically significant difference. 


\section{Results}

Patient characteristics in preoperative period are given in the Table 1. The three groups did not differ preoperatively with respect to mean age (Group I $44.72 \pm 9.19$ years, Group II $45.64 \pm$ 8.91years, Group III $46.44 \pm 9.29$ years), weight (Group I $65.96 \pm 6.83 \mathrm{Kg}$, Group II $64.76 \pm 6.17$ $\mathrm{Kg}$, Group III $64.88 \pm 6.70 \mathrm{Kg}$ ), systolic blood pressure (Group I $120.84 \pm 10.85 \mathrm{mmHg}$, Group II $119.88 \pm 9.88 \mathrm{mmHg}$, Group III $126.44 \pm 10.50$ $\mathrm{mmHg}$ ), diastolic blood pressure (Group I 69.76 $\pm 6.63 \mathrm{mmHg}$, Group II $69.00 \pm 6.60 \mathrm{mmHg}$, Group III $71.08 \pm 6.89 \mathrm{mmHg}$ ) with $\mathrm{P}$ value $>0.05$.

Table 1: Demographic data and preoperative parameters as mean $\pm \mathrm{SD}$

\begin{tabular}{|c|c|c|c|c|}
\hline \multirow{2}{*}{$\begin{array}{l}\text { Demographic } \\
\text { data and } \\
\text { baseline } \\
\text { operative } \\
\text { parameters }\end{array}$} & Group I & $\begin{array}{l}\text { Group } \\
\text { II }\end{array}$ & Group III & \multirow{2}{*}{$\begin{array}{l}P \\
\text { val } \\
\text { ue }\end{array}$} \\
\hline & Control & $\begin{array}{l}\text { Clonidin } \\
\text { e }\end{array}$ & $\begin{array}{l}\text { Dexmedet } \\
\text { omidine }\end{array}$ & \\
\hline Age (years) & $\begin{array}{l}44.72 \pm \\
9.19\end{array}$ & $\begin{array}{l}45.64 \pm \\
8.91\end{array}$ & $\begin{array}{l}46.44 \pm \\
9.29\end{array}$ & $\begin{array}{l}0.8 \\
01\end{array}$ \\
\hline Weight (kg) & $\begin{array}{l}65.96 \pm \\
6.83\end{array}$ & $\begin{array}{l}64.76 \pm \\
6.17\end{array}$ & $\begin{array}{l}64.88 \pm \\
6.70\end{array}$ & $\begin{array}{l}0.7 \\
77\end{array}$ \\
\hline $\begin{array}{l}\text { Male: Female } \\
\text { percentage }\end{array}$ & $76 \%$ & $72 \%$ & $72 \%$ & $\begin{array}{l}0.9 \\
34\end{array}$ \\
\hline SBP (mmHg) & $\begin{array}{l}120.84 \pm \\
10.85\end{array}$ & $\begin{array}{l}119.88 \pm \\
9.88\end{array}$ & $\begin{array}{l}126.44 \pm \\
10.50\end{array}$ & $\begin{array}{l}0.0 \\
62\end{array}$ \\
\hline $\mathrm{DBP}(\mathrm{mmHg})$ & $\begin{array}{l}69.76 \pm \\
6.63\end{array}$ & $\begin{array}{l}69.00 \pm \\
6.60\end{array}$ & $\begin{array}{l}71.08 \pm \\
6.89\end{array}$ & $\begin{array}{l}0.5 \\
43\end{array}$ \\
\hline $\mathrm{PR} / \mathrm{min}$ & $\begin{array}{l}71.76 \pm \\
6.98\end{array}$ & $\begin{array}{l}72.52 \pm \\
6.75\end{array}$ & $\begin{array}{l}72.32 \pm \\
6.67\end{array}$ & $\begin{array}{l}0.9 \\
2\end{array}$ \\
\hline \multicolumn{5}{|c|}{$\begin{array}{l}\mathrm{SBP}=\text { Systolic blood pressure, } \mathrm{DBP}=\text { Diastolic blood pressure, } \\
\mathrm{PR}=\mathrm{Pulse} \text { rate }, \mathrm{SD}=\text { Standard deviation }\end{array}$} \\
\hline
\end{tabular}

As shown in Table 2, it was observed that in group III there was faster onset of sensory and motor block compared to group II and group I (sensory block in Group I $13.04 \pm 1.27 \mathrm{~min}$, Group II $13.72 \pm 1.24$ min, Group III $11.60 \pm 1.08$ min, motor block in Group I $16.92 \pm 1.04 \mathrm{~min}$, Group II $17.16 \pm 1.03$ min, Group III $15.52 \pm$ $1.05 \mathrm{~min}$ ) with $\mathrm{P}$ value $<0.05$.
Table 2: Onset of sensory and motor blockade

\begin{tabular}{|c|c|c|c|c|}
\hline & Group I & Group II & Group III & \multirow[b]{2}{*}{ P Value } \\
\hline & $\begin{array}{l}\text { Mean } \pm \\
\text { Sd }\end{array}$ & $\begin{array}{l}\text { Mean } \pm \\
\text { Sd }\end{array}$ & Mean $\pm \mathrm{Sd}$ & \\
\hline $\begin{array}{l}\text { Onset of } \\
\text { sensory } \\
\text { block } \\
\text { (min) }\end{array}$ & $\begin{array}{l}13.04 \pm \\
1.27\end{array}$ & $\begin{array}{l}13.72 \pm \\
1.24\end{array}$ & $11.60 \pm 1.08$ & 0.006 \\
\hline $\begin{array}{l}\text { Onset of } \\
\text { motor } \\
\text { block } \\
\text { (min) }\end{array}$ & $\begin{array}{l}16.92 \pm \\
1.04\end{array}$ & $\begin{array}{l}17.16 \pm \\
1.03\end{array}$ & $15.52 \pm 1.05$ & $<0.001$ \\
\hline
\end{tabular}

As shown in Table 3 the difference in three groups with respect to duration of sensory and motor block as well as duration of analgesia (measured till a visual analogue score of $>3$ was noted) was found to be statistically highly significant $(\mathrm{p}<0.001)$ with group II having a much longer duration of motor block compared to group I and group III having longest duration.

Table 3: Duration of sensory and motor blockade and duration of post-operative analgesia

\begin{tabular}{|c|c|c|c|c|}
\hline & Group I & Group II & Group III & $\begin{array}{l}\mathbf{P} \\
\text { Valu } \\
\text { e }\end{array}$ \\
\hline & $\begin{array}{l}\text { Mean } \pm \\
\text { Sd }\end{array}$ & Mean $\pm \mathrm{Sd}$ & Mean $\pm \mathrm{Sd}$ & \\
\hline $\begin{array}{l}\text { Duration } \\
\text { of sensory } \\
\text { block } \\
\text { (min) }\end{array}$ & $\begin{array}{l}359.20 \pm \\
2.97\end{array}$ & $\begin{array}{l}561.60 \pm \\
33.13\end{array}$ & $\begin{array}{l}728.40 \pm \\
34.12\end{array}$ & $\begin{array}{l}<0.0 \\
01\end{array}$ \\
\hline $\begin{array}{l}\text { Duration } \\
\text { of motor } \\
\text { block } \\
\text { (min) }\end{array}$ & $\begin{array}{l}292.80 \pm \\
18.38\end{array}$ & $\begin{array}{l}488.80 \pm \\
29.20\end{array}$ & $\begin{array}{l}706.00 \pm \\
25.50\end{array}$ & $\begin{array}{l}<0.0 \\
01\end{array}$ \\
\hline $\begin{array}{l}\text { Duration } \\
\text { of } \\
\text { analgesia } \\
\text { (min) }\end{array}$ & $\begin{array}{l}436.00 \pm \\
19.79\end{array}$ & $\begin{array}{l}623.20 \pm \\
31.85\end{array}$ & $\begin{array}{l}803.20 \pm \\
42.00\end{array}$ & $\begin{array}{l}<0.0 \\
01\end{array}$ \\
\hline
\end{tabular}

As shown in Figure 1, the rescue analgesia (used being injection diclofenac sodium $75 \mathrm{mg}$ intravenous in $100 \mathrm{ml}$ normal saline) used in group III was least as was significant decrease in 24-hour analgesic consumption in group III and group II compared to group I (statistically significant $\mathrm{p}$ value $<0.001$ ). 
Figure 1: Number of doses of analgesics (diclofenac $75 \mathrm{mg}$ i.v.) in 24 hours

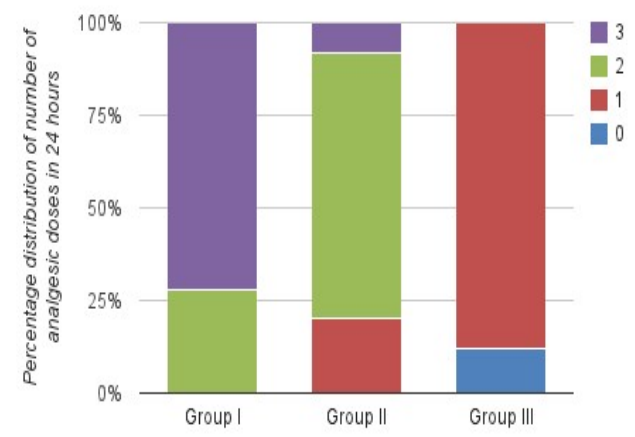

\section{Discussion}

Brachial plexus blockade is the cornerstone of regional anaesthesia practice of most anaesthesiologists. Brachial plexus block results in anaesthesia that is limited to a restricted portion of body, not disturbing the metabolism of rest of the body, early ambulation and early discharge of the patient. The usual indications for supraclavicular brachial plexus block are surgeries of hand and arm.

Nerve blocks with long acting local anaesthetics such as ropivacaine or bupivacaine are beneficial for improved postoperative pain therapy, but the duration of block is still not sufficient to avoid the postoperative use of opioids. Alternatively, perineural catheters can be used to prolong the duration of analgesia, however, in comparison with single-shot blocks, the insertion of peripheral nerve catheters is more timeconsuming, costly, possibly more painful for the patient, has possible higher complication rates (e.g. infection, dislodgment), and needs more postoperative care. To improve the quality of block and prolong the duration of postoperative analgesia various adjuvants like epinephrine, clonidine, opioids, bicarbonate, neostigmine, verapamil, butorphenol have been added to local anaesthetics when used in brachial plexus block. ${ }^{7}$ Adjuvants not only improve the quality of block but also improve the duration of analgesia which decreases the need for post-operative analgesics and continuous perineural catheters.

In this study it was observed that there was significant increase in mean duration of sensory and motor block in both group II and group III. This increase in duration was found to be statistically highly significant with the addition of dexmedetomidine in comparison to clonidine and control group. This prolonged duration of sensory and motor blockade following the addition of clonidine and dexmedetomidine to local anaesthetics in peripheral nerve blocks has also been reported in earlier studies by Kenan Kaygusuz MD et al and Singelyn FJ et al. ${ }^{6,8}$ Although in some studies addition of clonidine to local anaesthetics did not show any advantage of increasing duration of block as Erlacher W et al found that the addition of clonidine to ropivacaine $0.75 \%$ did not lead to any advantage of block of the brachial plexus when compared with pure ropivacaine $0.75 \% .{ }^{9}$ However, most of the studies report the advantages both in terms of quality and duration of block. Chakraborty $\mathrm{S}$ et al found that the addition of a small dose $(30 \mathrm{mcg}$ ) of clonidine to $0.5 \%$ bupivacaine significantly prolonged the duration of analgesia without producing any clinically important adverse reactions other than sedation. ${ }^{10}$ The use of dexmedetomidine in group III resulted in faster onset of sensory and motor block. The mechanism of faster onset of block is mediated through blockade of the hyperpolarizationactivated cation current (Ih current), which is important to bring a peripheral nerve back to the resting potential. ${ }^{11}$ The role of clonidine as adjuvant to ropivacaine in faster onset of sensory and motor block is controversial, with most of previous studies showing no effect on onset of block but use of dexmedetomidine with local anaesthetics have shortened the onset time of sensory and motor block. ${ }^{12,13}$

There was significant decrease in analgesic consumption in the postoperative period with the use of adjuvants dexmedetomidine and clonidine. There have been four proposed mechanisms for the this:- centrally mediated analgesia, $\alpha_{2} \beta$ adrenoceptor-mediated vasoconstrictive effects, attenuation of inflammatory response and direct action on peripheral nerve. ${ }^{14,15}$ The prolongation of analgesia after neural blockade with use of alfa agonists resulted from increase in potassium conductance and blocking the conduction of $\mathrm{C}$ and $\mathrm{A}$ fibers. ${ }^{16}$ Besides, clonidine also enhances lignocaine-induced inhibition of C-fiber compound action potential. Lipophilic nature of clonidine allows rapid absorption into cerebrospinal fluid and binding to adrenoceptor of spinal cord causing blockade at primary afferent terminals (both spinal as well as peripheral nerve endings). ${ }^{17}$ Centrally alfa-2 
agonists produce analgesia and sedation by inhibition of substance $\mathrm{P}$ release in the nociceptive pathway at the level of dorsal root neuron and by activation of alfa-2 adrenoreceptors in locus coeruleus. ${ }^{18}$

There was no clinical or statistical change in respiratory rate or arterial saturation $\left(\mathrm{S}_{\mathrm{P}} \mathrm{O}_{2}\right)$ at all measured intervals in any of the three groups. Singh $\mathrm{S}$ et al and Kenan Kaygusuz MD et al also used on clonidine and dexmedetomidine as adjuvants to local anaesthetics in dose of $1 \mathrm{mcg} / \mathrm{kg}$ body weight in which there was no significant difference in the ventilatory frequency or oxygen saturation. ${ }^{6,19}$ Also the haemodynamic parameters (heart rate, mean blood pressure) recorded did show statistically insignificant difference in the three groups with clonidine and dexmedetomidine resulting lower hear rate and blood pressure however there was no need for pharmacological intervention. However, our haemodynamic data do not allow a conclusion regarding the safety in cardiovascular compromised patients. This was in accordance with the studies done by adding clonidine and dexmedetomidine added to bupivacaine, or levobupivacaine. ${ }^{20}$

Therefore, in our present study, we have found that addition of 50microgram dexmedetomidine to $0.5 \%$ ropivacaine in supraclavicular brachial plexus block decreased onset time of sensory and motor block and prolonged duration of postoperative analgesia and effect was significantly more than clonidine and control group.

\section{Conclusion}

Therefore, in present study it was found that addition of clonidine and dexmedetomidine to $0.5 \%$ ropivacaine are effective in supraclavicular brachial plexus block. However, dexmedetomidine is a better alternative to clonidine to obtain early onset and prolonged duration of sensory and motor block and postoperative analgesia.

\section{References}

1. Bonica JJ, Moore DC, Orlov M. Brachial plexus block. Am J Surg 1949; 78: 65-79. https://doi.org/10.1016/0002-9610(49)90186-5

2. D. Bruce Scott, Alistair Lee, Denise Fagan, Geoffrey M. R. Bowler, Peter Bloomfield, Rolf Lundh. Acute toxicity of ropivacaine compared with that of bupivacaine. AnesthAnalg 1989; 69(5): 563-69.

PMid: 2679230

3. Landau R, Schiffer E, Morales M, Savoldelli G, Kern C. The dose-sparing effect of clonidine added to ropivacaine for labor epidural analgesia. AnesthAnalg. 2002; 95(3): 728-34. PMid:12198061

4. El Saied AH, Steyn MP, Ansermino JM. Clonidine prolongs the effect of ropivacaine for axillary brachial plexus blockade. Can J Anesth 2000; 47(10): 962-67.

https://doi.org/10.1007/BF03024866

PMid: 11032270

5. Virtanen R, Savola JM, Saano V, Nyman L. Characterization of the selectivity, specificity and potency of medetomidine as an alpha 2adrenoceptor agonist. Eur J Pharmacol. 1988;150:9-14

https://doi.org/10.1016/0014-2999(88)90744-3

6. Kenan Kaygusuz MD et al. Effects of Adding Dexmedetomidine to Levobupivacaine in Axillary Brachial Plexus Block Current Therapeutic Research 2012; 73(3): 103-111. PMid:24648597

7. Murphy DB, Mccartney CJ, Chan. Novel analgesic adjuncts for brachial plexus block: a systemic review. AnesthAnalg 2000; 90: 112228. https://doi.org/10.1097/00000539-200005000$\underline{00023}$

8. Singelyn FJ, Dangoisse M, Bartholomee S, Gouverneur JM. Adding clonidine to mepivacaine prolongs the duration of anaesthesia and analgesia after brachial plexus block. RegAnesth 1992; 17: 148-50.

PMid:1606097

9. Erlacher W, Schuschnig C, Orlicek F, Marhofer $\mathrm{P}$, Koinig H, Kapral S. The effects of clonidine on ropivacaine $0.75 \%$ in axillary perivascular brachial plexus block. ActaAnaesthesiol Scand. 2000; 44(1): 53-57.

https://doi.org/10.1034/j.13996576.2000.440110.x

10. Chakraborty S, Chakrabarti J, Mandal MC etal.Effect of clonidine as adjuvant in bupivacaine induced supraclavicular brachial plexus block: A randomized controlled trial. Indian J Pharmacol 2010;42(2):74-7.

https://doi.org/10.4103/0253-7613.64498 PMid:20711369 PMCid:PMC2907018

11. Lönnqvist PA. Alpha-2 adrenoreceptor agonists as adjuvants to peripheral nerve blocks in children-is there a mechanism of action and should we use them? PaediatrAnaesth. 2012;22(5):421-424. PMid: 22486904

12. D. Marhofer, S. C. Kettner, P. Marhofer, S. Pils, M. Weber, M. Zeitlinger. Dexmedetomidine as an adjuvant to ropivacaine prolongs peripheral nerve 
block: a volunteer study. BJA.2013; 110 (3): 438-

442.

https://doi.org/10.1093/bja/aes400

PMid:23161360

13. Jaiswal R, Bansal T, Mehta S, Ahlawat G. A study to evaluate the effect of adding clonidine to ropivacaine for axillary plexus blockade. Asian journal of pharmaceutical and clinical research. 2013: 6(3);165-68.

14. Brummett CM, Norat MA, Palmisano JM, Lydic R. Perineural administration of dexmedetomidine in combination with Bupivacaine enhances sensory and motor blockade in sciatic nerve block without inducing neurotoxicity in rat. Anesthesiology 2008;109:502-11.

PMid:18719449, PMCID: PMC2709835.

15. Swami SS, Keniya VM, Rao R. Comparison of dexmedetomidine and clonidine ( $\alpha 2$ agonist drugs) as an adjuvant to local anaesthesia in supraclavicular brachial plexus block: A randomised double-blind prospective study. Current Therapeutic Research. 2012: 73(3); 103111.

16. Kamibayashi T, Maze M. Clinical uses of alpha 2 -adrenergic agonists. Anesthesiology

2000;93:1345-9.

PMid: 11046225

17. Madan R, Bharti N, Shende D, Khokhar SK, Kaul HL. A dose response study of clonidine with local anesthetic mixture for peribulbar block: A comparison of three doses. AnesthAnalg 2001; 93:1593-7.

https://doi.org/10.1097/00000539-20011200000056

PMid:11726451

18. Guo TZ, Jiang JY, Buttermann AE, Maze M. Dexmedetomidine injection into the locus ceruleus produces antinociception. Anesthesiology 1996;84:873-81

PMid:8638842

19. Singh S, Aggarwal A. A randomized controlled double blinded prospective study of the efficacy of clonidine added to bupivacaine as compared with bupivacaine alone used in supraclavicular brachial plexus block for upper limb surgeries. Indian J Anaesth 2010; 54(6): 552-57. https://doi.org/10.4103/0019-5049.72646 PMid:21224974 PMCid:PMC3016577

20. 20.Lin YN, Li Q, Yang RM, Mao ZX, Liu JC. Addition of dexmedetomidine to ropivacaine improves cervical plexus block. Acta Anaesthesiol Taiwan. 2013 Jun; 51(2): 63-6. https://doi.org/10.1016/j.aat.2013.06.001 